\title{
Cashew Production as a Climate Change Adaptation and Mitigation Tool for Agriculture
}

\author{
Advances in Earth and Environmental Science
}

Research Article

Victor Adjei $^{{ }^{*}}$, Mawusi Adzo Alormu ${ }^{2}$

${ }^{1}$ Climate Change and Sustainable Development, University of Ghana, Legon, Accra, Ghana

${ }^{2}$ Development and Environmental Studies, Wisconsin International University College, Accra, Ghana

\author{
*Correspondence author \\ Victor Adjei \\ Climate Change and Sustainable Development \\ University of Ghana \\ Legon \\ Accra \\ Ghana
}

Submitted : 7 Oct 2020 ; Published : 3 Dec 2020

\begin{abstract}
The study was conducted in the Wenchi Municipality in the forest/savannah transitional agro-ecological zone of Ghana to analyse the dual role of cashew production as a tool for adaptation and greenhouse gas mitigation in the face of climate change and variability. The study used primary data to collect data from 400 randomly selected cashew farmers from 9 farming communities in the Municipality through the administration of questionnaire. Key informant interview with the help of semi-structured interview guide was also held drawing 6 participants from the study area. Cashew production data from the Department of Agriculture in the municipality beefed up the analysis.

It was observed in the study that the major source of income to the respondents was cashew production (57.0\%) followed by maize (25.5\%). The most affected crops by the changing climate were maize $(52.3 \%)$, yam $(15.0 \%)$ groundnut (13.5\%) and vegetables (10.8\%), where the least affected crop was cashew (2.3\%). It was realized that the major source of livelihood was cashew cultivation (56\%) hence it was not out of place for the respondents themselves to enforce by-laws on bush fire during the harmattan seasons (winter). The presence of cashew farming in the study area had resulted in enhancement in mitigation strategies such as reduction in tillage, preservation of ecosystem, reduced 'slash and burn' method of farming and so on. Again, the rampant seasonal bush fire in the area during dry season (winter) of which peasant farmers used to prepare their lands or unscrupulous people hid behind for hunting according to the respondents had seen a decline.
\end{abstract}

Keywords/Phrase: adaptation, mitigation, greenhouse, sink, sequestration, anthropogenic.

\section{Introduction}

Agriculture lands (i.e. lands used for agricultural production comprising of managed grasslands, cropland and permanent crops such as agro-forestry and dedicated bio-energy crops) occupy approximately $37 \%$ of the earth's surface [1]. Agriculture emits substantial amount of Greenhouse Gases into the atmosphere, primarily carbon dioxide $\left(\mathrm{CO}_{2}\right)$, methane $\left(\mathrm{CH}_{4}\right)$ and nitrous oxide $\left(\mathrm{N}_{2} \mathrm{O}\right)$. Agriculture accounts for about $49 \%$ of terrestrial anthropogenic emissions $66 \%$ of global anthropogenic nitrous oxide emissions and $15 \%$ of anthropogenic carbon dioxide emissions [2] [3]. Carbon in the form of carbon dioxide $\left(\mathrm{CO}_{2}\right)$ is presently accumulating in the atmosphere at the rate of approximately 1.4 petagram per year ( $\mathrm{pg} / \mathrm{yr})$ ( $\mathrm{pg}=1$ billion tonnes) due to fossil fuel combustion and land use change. The Intergovernmental Panel on Climate Change (IPCC) in its Second Assessment Report estimated that it may be possible, over the course of the next 50 to 100 years, to remove 40 to $80 \mathrm{Pg}$ of the carbon by sequestering it in cropland soils [4]. Therefore, soil carbon sequestration on agricultural land alone might offset the effects of fossil fuel emission and land use change for one or two decades or even longer.

Atmospheric concentrations of carbon dioxide can be reduced either by lowering emissions or by taking carbon dioxide out of the atmosphere, and it is strong in terrestrial, oceanic or freshwater aquatic ecosystems. Agriculture contributes greatly to global greenhouse gas emissions and therefore to anthropogenic climate change. However, agriculture has also huge prospects to contribute to climate change mitigation. Moreover, agriculture is strongly affected by climate change. The direct contribution of agrarian sector to total global GHG emission is approximately $10-15$ per cent. With regards to indirect contribution of land use change (viz. deforestation and cultivation of peatlands) and input production as well, this share increases to more than $30 \%$ [5] [6]. 
The agricultural soils and forestry sectors have received much current concern as a result of their prospect to store and retain carbon and thus limit emissions to the lower atmosphere. These sectors too offer the potential for sustainable management of ecosystem; both sectors present an opportunity to remedy land degradation and desertification or to rehabilitate degraded land.

A transition to the use of perennial crops or reduced tillage practices tends to surge carbon sink and decrease $\mathrm{CO}_{2}$ emission. Crops produced using no-tillage systems have sequestered more carbon than crops established using conservation or conventional tillage practices [7] [8]. No tillage practices slow the decomposition of crop residue and therefore reduce emissions and sequester more soil carbon.

Ghana's total greenhouse gas emissions grew 20 per cent from 1990-2011 [9]. The average annual change during this period was 0.9 per cent, with sector-specific mean annual change as follows: LUCF (-0.7\%), energy (6.4\%), agriculture $(1.9 \%)$, waste $(6.8 \%)$ and IP $(3.2 \%)$. Ghana's Third National Communication (TNC) to UNFCCC notes a rise in GHG emissions from land, which increased from -3.0 $\mathrm{MtCO}_{2}$ e to $1.3 \mathrm{MtCO}_{2} \mathrm{e}$ during this period, largely due to deforestation. Ghana's estimated annual deforestation rate of $2.2 \%$ from 2005 to 2010 was the sixth highest in the world. However, the TNC notes that Ghana's national reforestation plan led to decreased emissions from land-use change between 2010 and 2012 [9]. The main objective of the paper was to assess the contribution of cashew production in the field of adaptation and carbon mitigation.

The main objective of the paper was to assess the contribution of cashew production in the field of adaptation and carbon mitigation.

\section{Materials and Methods}

The study was conducted in the Wenchi Municipality in the Bono Region (formerly Brong Ahafo Region) of Ghana. The region is the major cashew production zone in the country [10]. Wenchi is located in the Forest/Savanna transition agroecological zone with a population of 89,739 . It occupies an area of 7,619.7 square kilometres with 180 communities [11]. The area lies between latitude $7^{\circ} 27 \mathrm{~N}$ and $8^{\circ} 30 \mathrm{~N}$ and longitudes $1{ }^{\circ} 30 \mathrm{~W}$ and $2^{\circ} 36 \mathrm{~W}$. The economy of the Municipality is driven by agriculture and its related activities. The sector accounts for $65.2 \%(33,817)$ of the active labour force compared with $57.0 \%$ at the nationwide level [12].

The study area has a bimodal rainfall pattern with peaks in June/July as well as September/October with a marked dry season from November to March. Average annual rainfall and temperature are $800-1200 \mathrm{~mm}$ and $26^{\circ} \mathrm{C}$ respectively [13].

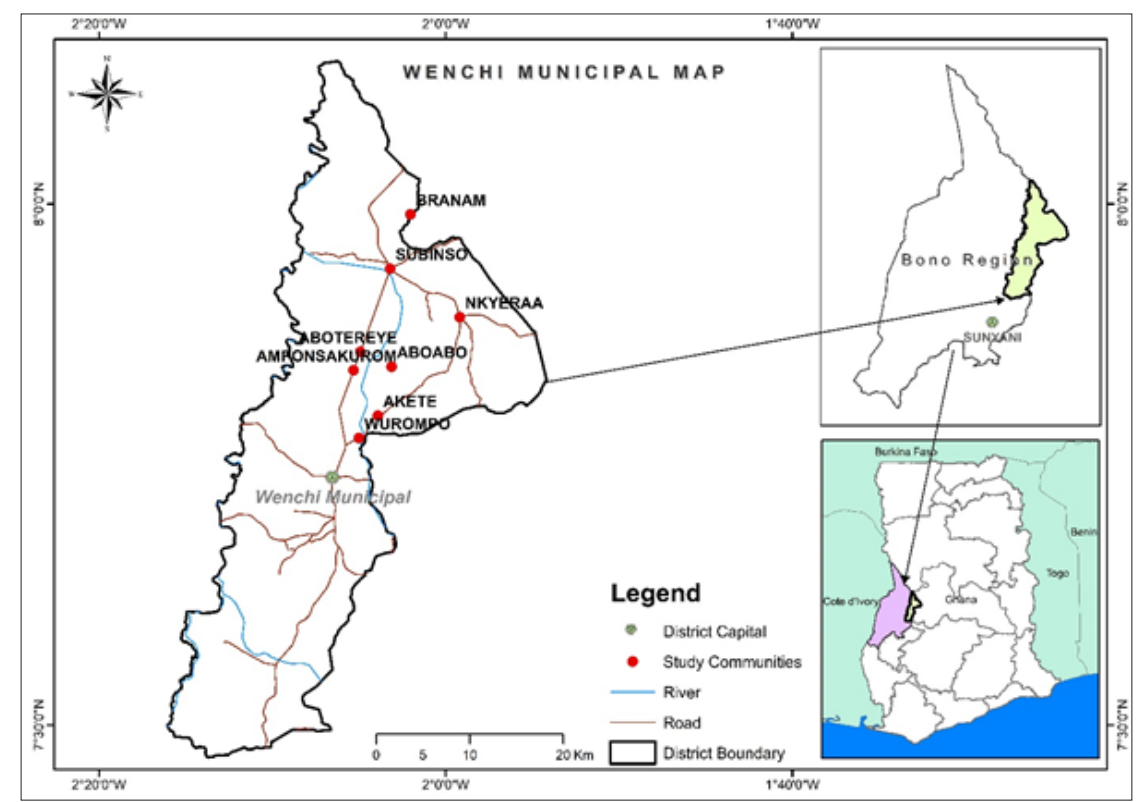

Figure 1: Map of Wenchi Municipality showing the study area

\section{Data collection and Methods}

The study used both primary and secondary data. Secondary data were articles, journals, and literature works of other scholars and so on. Primary data were questionnaire administration and cashew data from Wenchi Municipal Assembly- Agricultural department. The questionnaire was purely cross-sectional. It was collected from 400 respondents (cashew farmers) from nine communities. The communities were Abotareye (55), Aboabo (30), Subenso No 1 (70), Subenso No 2 (40),
Akefe (15), Nkyeraa (45), Brenam (55), Wurampo (20) and Amponsakrom (70).

The farmers were randomly selected to answer questions pertaining to climate (temperature and rainfall), farming activities, farmers' association, income accrued from cashew, demographic information and so on. The component of the respondents comprises both male (87\%) and female farmers $(13 \%)$. 
Semi-structure interviews were also conducted with 6 key informants. The discussions were audio-recorded with the permission from the informants and the data were later transcribed thematically and analysed. Analytical summaries of the interviews were developed to assist in the identification of the overarching themes for the study.

\section{Results and Discussion}

According to there are interactions between mitigation and adaptation in the agricultural sector. Mitigation and adaptation may take place concurrently, but may differ in space and time. The benefits of climate change mitigation actions would be 'harvested' in decades unlike improved adaptation actions which can be realised in short, medium or long term [1].

\section{Evidence of changing climate}

In the fourth assessment report of IPCC, the Earth's climate is warming [14]. The Earth has warmed about $0.6^{\circ} \mathrm{C}$ during the last century, with majority of the warming years occurring during the period 1920-1940 and during the last three decades However, the increases in the atmospheric temperatures are not evenly distributed across the surface of the globe with fastest warming occurring on land than the ocean [14].

The corresponding rise in temperature has led to rise in evaporation resulting in more precipitation (Solomon et al., 2007), which generally increased over lands found north of latitude $30^{\circ} \mathrm{N}$ from 1900 to 2005 . There was a decline of the phenomenon over the lower latitudes (over the tropics) since 1970s, and there has been no conspicuous trend of precipitation globally over the past 100 years, with a vast variability in pattern over space and time.

According to Adjei and Kyerematen (2018), precipitation in the forest/savannah ecological zone of Ghana has experienced a decline of $9.6 \%$ from 1960 to 2014 . The paper has it that the rainfall regime over the sub-region was higher between 1960 and 1987 but realized reduction between 1988 and 2014.

Crop diversification is normally promoted as a practice to achieve climate resilience. But the benefits of food crop diversification rest on the household resource and the immediate environmental stress. The dominant climatic impact that affects food crop production in the forest/savannah zone in Ghana comes from precipitation. The study revealed that most of the farmers $(98.5 \%)$ were aware that the rainfall trajectory has changed with few still sceptical (1.5\%). As some of the respondents had observed the changes over the past five years $(58.8 \%)$, others were of the view that it had existed for the past 10 years $(28.3 \%)$ or more $(8.0 \%)$. The nature $(\mathrm{S})$ of the changing climate according to the study was reduction in rainfall amount $(51.3 \%)$, erratic/irregular $(21.3 \%)$ or both $(22.0 \%)$. Very few of the respondents had the view that the rainfall had rather increased over the past few years $(4.0 \%)$. It was observed that water stress that had disparately characterised the forest/ savannah ecological zone had affected crops. Food crops were much impacted on than cash crops. The most affected crops were maize $(52.3 \%)$, yam $(15.0 \%)$ groundnut $(13.5 \%)$ and vegetables $(10.8 \%)$. The least affected crop was cashew $(2.3 \%)$ per the farmers' response. The study corroborates a paper by Boko et al. (2007) that climate change has a direct impact on agricultural production since agricultural system depends on the nature of the climate.

\begin{tabular}{|l|l|l|l|l|l|}
\hline \multicolumn{2}{|c|}{} & Frequency & Percent & $\begin{array}{l}\text { Valid } \\
\text { Percent }\end{array}$ & $\begin{array}{l}\text { Cumulative } \\
\text { Percent }\end{array}$ \\
\hline \multirow{4}{*}{ Valid } & Maize & 209 & 52.3 & 52.3 & 52.3 \\
\cline { 2 - 6 } & Groundnut & 54 & 13.5 & 13.5 & 65.8 \\
\cline { 2 - 6 } & Yam & 60 & 15.0 & 15.0 & 80.8 \\
\cline { 2 - 6 } & Vegetables & 43 & 10.8 & 10.8 & 91.5 \\
\cline { 2 - 6 } & Cashew & 9 & 2.3 & 2.3 & 93.8 \\
\cline { 2 - 6 } & Others & 25 & 6.3 & 6.3 & 100 \\
\cline { 2 - 6 } & Total & 400 & 100.0 & 100.0 & \\
\hline
\end{tabular}

Table 1: crops affected by changing climate

\section{Adaptation role of cashew production in the municipality}

Table 1 explains why the majority of the respondents had resorted to cashew farming. Since cashew trees were resilient to the irregular rainfall, almost every household had a piece of land for cashew farming (informant) in the study area. It was noticed that the major benefits of cashew cultivation were provision of employment and income $(56.8 \%)$. With regard to employment, apart from cashew owners, people such as hand pickers, pruners, buyers, chainsaw operators etc. earned their living during on-farm season. Some of the respondents were of the view that maize $(25.5 \%)$ and yam $(11.5 \%)$ also cushioned them financially. The Figure 1 summarised the economic benefits of crops to the respondents.

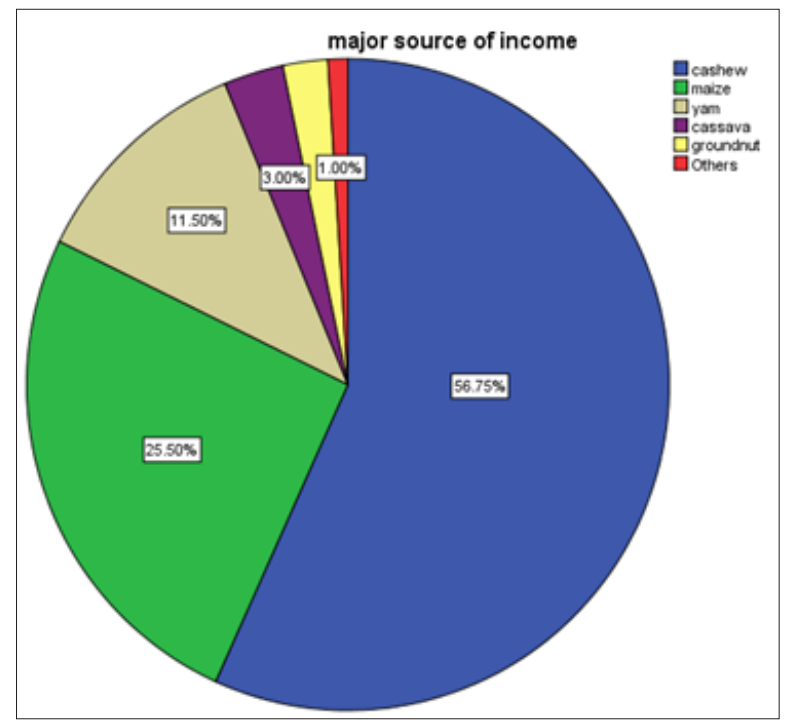

Figure 2: major source of income to farmers

\section{Diversification of local economy}

It is worthy to note that cashew was non-native crop to the economy of Ghana. Ghana resorted to cashew production around 1990's when she wanted to embark on an Economic Recovery Programme (ERP), hence diversifying the economy base of the country was the priority. The farmers were zealous 
to augment production as there was access to market and payment and this led to a rise in export from 50 metric tonnes in 1991 to 3,571 metric tonnes in 1997 [15] [16]. This had a trickledown effect on the Municipality, and since the inception of the cash crop in the area in the early 90s, the production had been rising persistently (informants) as shown on Table 1. This has made the poor-resourced farmer whose food crop production being precariously fragile to the changing climate had somewhat adapted well to the phenomenon (informant). as he obtains regular income in its season.

The data from the Department of Agriculture in the Municipality clearly shows that between the year 2013 and 2017, there had been substantial percentage rise in area under cultivation (36\%) and production (285\%). With respect to production per yield, there was a considerable percentage change (183\%) from $2013(0.6 \mathrm{mt})$ to $2017(1.7 \mathrm{mt})$. The average percentage increase for the five years under review was $7.2 \%$ (area), $56.5 \%$ (production) and $36.6 \%$ (production per yield). This exponential increase in production from 2013 to 2017 was driven by the profit (53.4\%) accrued from cashew business and probably vulnerability of food crops (e.g. maize) to climate change (10.8\%).

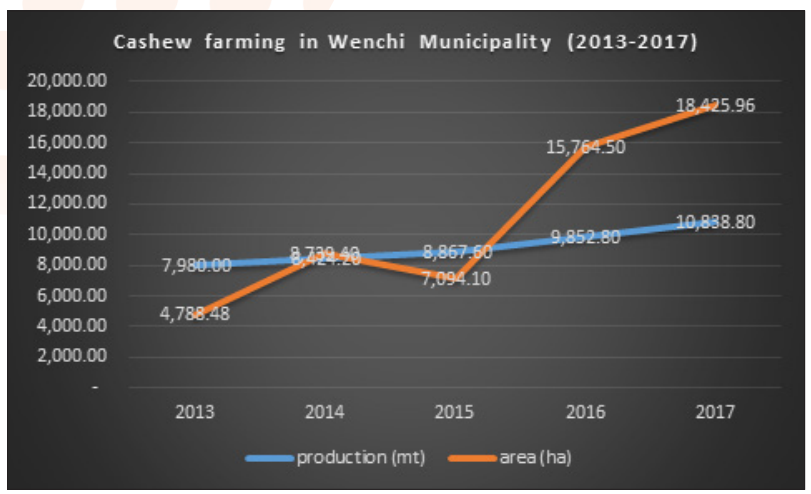

Figure 3: cashew area of cultivation (ha) and production (mt)

\section{Greenhouse gas mitigation}

Mitigation of greenhouse gas emissions associated with various agricultural practices and soil carbon sequestration can be attained through best management practices to a certain extent [17]. However, various agricultural practices can enhance soil carbon sequestration (Ecological Society of America, 2000). The control of greenhouse gas emissions nevertheless has become imperative globally. Although agriculture is a potential source of atmospheric carbon dioxide, farmlands can also serve as a sink or storage for carbon sequestered from atmospheric carbon dioxide. According to FAO (2019), greenhouse gas emissions from crop and livestock activities contribute some 5 billion metric tonnes of carbon dioxide equivalent $\left(\mathrm{CO}_{2 \mathrm{eq}}\right)$ to the atmosphere. Land use and land use change activities linked to agricultural practices release this quantity yearly, for instance, from deforestation and forest degradation or from drainage of carbon-rich organic soils, to make room for crops and livestock. Naturally, terrestrial sequestration is accomplished through forest and soil conservation practices that improve carbon storage (for instance, restoring and establishing new forest, wetlands and grasslands) or reduce
$\mathrm{CO} 2$ emissions through reduction in agricultural tillage and suppressing wild fire.

\section{Minimised/no tillage causing carbon sequestration}

The study area had been known as one of the major producers of maize in Ghana but the story had altered. The respondents ranked cashew first $(56.8 \%)$ followed by maize production $(25.5 \%)$ as major source of income. With respect to expansion of cashew lands, about $41.0 \%$ of respondents increased their farmlands through conversion of farmlands to cashew farming, $10.5 \%$ expanded their cashew lands through purchasing of lands whereas $20.0 \%$ enlarged their cashew lands on uncultivated lands. About 83.7 percent of farmers who convert their croplands to cashew production were maize farmers.

Moreover, per the data from the Agricultural Department of the Municipality, about $7.2 \%$ of arable land was lost to cashew farming annually. This means that business at usual (BAU), by 10 years' time, greater proportion of the food croplands would be lost to cashew production. As a matter of fact, practices of maize farming, for instance, increases GHG emission. Cultural practices of maize farming such as ploughing and application of fertilizer lead to a rise in carbon dioxide and nitrous oxide respectively. Since cashew farming does involve ploughing, the disturbances of the soil would reduce as these lands are surrendered to cashew cultivation. According to, reduction in soil disturbance and improved residue management have a vital repercussion on soil carbon sequestration [6]. Soil disturbance by tillage aerates the soil, enhancing microbial decomposition along with the release of carbon dioxide and loss of carbon. Soils are the largest terrestrial carbon sink on the planet [18]. A study by Sedjo and Sohngen (2012) suggests that no-till in agriculture approach forgoes the usual ploughing phase of the planting and harvesting process, thereby bypassing a process that causes disturbances in the soil and promotes carbon escape. The ploughing stage is undertaken largely to reduce weeding or to comb the soil and under a no-till regime, herbicides usually replace much of the ploughing of which $88.0 \%$ of the respondents in the study area had resorted to herbicides application. However, no-tillage practices may eventually benefit the poor-resourced farmer because maintaining sufficient carbon in the soil enhances crop yield apart from checking $\mathrm{C} 2 \mathrm{O}$ emission. More carbon within the soil promotes water quality, reduces nutrients loss, and checks soil erosion. It is worthy to note that agricultural soil management is the sole greatest contributor to greenhouse gas emissions from the United States agricultural production sector [18].

\section{Reduction in fire burning leading to abatement of Carbon Dioxide $\left(\mathrm{CO}_{2}\right)$ emission}

Apart from reduced or no-tillage from canopied cashew farmlands, the cashew trees/plants also cause carbon sink. Carbon dioxide is removed from the atmosphere and converted to organic carbon via the process of photosynthesis. Trees and plants absorb atmospheric carbon dioxide during this process (photosynthesis). As oxygen is released, carbon is on the other hand stored in the plants' leaves, trunks or roots. So, greening the economic landscape with perennial trees such as cashew 
enhances carbon sink. The study showed that arable land for cashew farming increased by $7.2 \%$ annually and this, more or less, has significant consequence on carbon sequestration. It was also revealed that cashew farming had reduced 'slash and burn' method of farming as well as annual bush fire in the Municipality, and this was occasioned by the presence of cashew farms (key informants). The majority of the respondents $(88 \%)$ had resorted to herbicides/weedicides use. It was realized that the major source of livelihood was cashew cultivation $(56 \%)$, hence it was not out of place for the respondents themselves to enforce laws on bush fire during the harmattan seasons (dry season). It is worthy to note that the temporarily darkening of the soil/landscape by burning reduces albedo and increases surface temperature for several weeks. The emission of carbon dioxide through wild fire also augments greenhouse gases. Fires, including decomposition, can emit a large amount of carbon sequestered within forest. As fires burn, trees release carbon dioxide back into the atmosphere (EPA, 2010).

Absence of application of fertilizer resulting in Nitrous Oxide $\left(\mathrm{N}_{2} \mathrm{O}\right)$ reduction

Another significant phenomenon noted was reduction in application of fertilizer due to crop diversification. As aforementioned, most of the cashew lands were formerly used to cultivate maize which is fertiliser-loving plant. But due to maize vulnerability to the changing climate, most of the peasant farmers were shifting their resources to cultivate tree crops (e.g. cashew) as the latter were resilient to irregular rainfall. As fertilizer is the sole contributor of nitrous oxide $\left(\mathrm{N}_{2} \mathrm{O}\right)$, reduction in application of fertilizer would help reduce emission. Some quantity of the nitrogen applied to soils through organic and mineral nitrogen fertilizers or green manure and other forms of plant residues is released as nitrous oxide, which is generated through soil microbial process. These nitrous oxide emissions account for more than 40 per cent of the sector's total emissions [17]. Therefore, diversification of maize farming to cashew cultivation may be helpful to reduce emission of greenhouse gas $\left(\mathrm{N}_{2} \mathrm{O}\right)$ if the practice will not compromise food security. The reason being that the GHGs (nitrous oxide and methane) have longer duration in the atmosphere and absorb more terrestrial radiation than carbon dioxide [19].

\section{Preservation of ecosystem leading to carbon sink}

Another significant benefit of cashew farming in the face of climate change was preservation of ecosystem. Most of the small-holder farmers rely on the ecosystem for fuel wood. Since one remarkable practice of cashew farming was pruning, the dependence of rural folk on the ecosystem had reduced. Approximately ninety per cent $(89.5 \%)$ of the cashew farmers pruned their cashew trees and this became the source of fuel for domestic purpose. This practice is likely to leave ecosystems undisturbed hence carbon sink might be improved. According to forests and undisturbed grasslands are known as carbon sinks because they can store large quantity of carbon in their vegetation and root systems for long periods of time [18].

\section{Conclusion}

Natural carbon sequestration comprises oceans, forest and soil. Studies have pointed out that different tillage operations and good crop management strategies can have influence on carbon sequestration in arable lands. Agricultural practices such as no/minimised tillage, avoidance of slash and burn methods, incorporating leguminous and perennial forages into crop rotations, minimization of application of fertilizer and eradicating fallow periods can help reduce greenhouse gas emissions. Research has proven that high carbon levels have indispensable benefit as they enhance soil structure, fertility and soil life consequently improving plant health, water holding and retention capacity, resistant against drought and extreme weather parameters.

Cultural practices associated with cashew cultivation have numerous advantages that can help improve carbon sink but attention of the globe is now shifted to other bigger lenses neglecting those minor ones. However, there is an adage that "little drop of water makes a mighty ocean". Therefore, there is the need to encourage cashew production as well as other cash crops because of their dual roles as increasing farmers' adaptive capacity and GHGs mitigation [20] [21] [22].

\section{References}

1. FAOSTAT (2005). FAOSTAT Agricultural Data. http:// faostat.fao.org/faostat/collections? Version ext \& has bulk 0\&subset agriculture (accessed 30th Sept. 2019)

2. FAO (2003). Unlocking the Water Potential of Agriculture.

3. Robertson G P, P R Grace (2004) Greenhouse gas fluxes in tropical and temperate agriculture: The need $f \quad o \quad r$ a full-cost accounting of global warming potentials. Environment, Development and Sustainability 6: 51-63.

4. Cole C V et al. (1995). Agricultural options for mitigation of greenhouse gas emissions. In: Climate Change Impacts, Adaptations and Mitigation of Climate Change: Scientific Technical Analysis. IPCC Working Group II, Cambridge University Press. pp. 7450-7771.

5. Smith P, Martino D, Cai Z, Gwary, Janzen H, Kumar P, McCarl B, Ogle S, O’Mara F, Rice C, Scholes B, Sirotenko O, Agriculture, Metz B, Davidson O R, Bosch P R, Dav R, Meyer L A (2007) (Eds.), Climate Change Mitigation. Contribution of Working Group III to the Fourth Assessment Report of the Intergovernmental Panel onClimate Change. Cambridge University P ress, Cambridge, United Kingdom and New York, USA

6. Bellarby J, Foereid B, Hastings A, Smith P (2008) Cool Farming: Climate impacts of agriculture and mitigation potential. Greenpeace International, Amsterdam, the Netherlands.

http://www.greenpeace.org/international/Global/ international/planet-2/report/2008/1/cool-farming-fullreport [15.02.2011]

7. Bruce J P, M. Frome, E. Haites, H. Janzen, R. Lal, K. Paustian (1999) Carbon sequestration in soils. J. $S$ o $i \quad l$ Water Conserv. 54(1): 382-389. 
8. Six J, E T Elliott, K Paustian (2000) Soil macroaggregate turnover and microaggregate formation: A mechanism for $\mathrm{C}$ sequestration under no-tillage agriculture. Soil Biol. Biochem. 32: 2099-2103. sSkinner, R. H. 2007.

9. Greenhouse Gas Emission in Ghana, 2012 Analytical Report

10. Wongnaa C A ,Awunyo-Vitor.D (2013) Profitability analysis of cashew production in Wenchi municipality in Ghana. FAO 2012. Gender inequalities in rural employment in Ghana. An overview. Food and Agricultural Organization. Retrieved from http://www.fao.org/docrep/016/ap090e/ap090e00.pdf on 18.12.18.

11. Ghana Statistical Service (2016) Statistics for Development and Progress: Gros Domestic Product 2014. Retrieved on 12th January from www. statsghana.gov.gh

12. Ghana Statistical Service (2010) National Analytical Report 2010 Population and Housing Census Ghana Statistical Service

13. Adjei-Nsiah S, Kerma M (2012) Climate Change and Shift in Cropping System: From Cocoa to Maize B a s e d Cropping System in Wenchi Area of Ghana. British Journal of Environment \& Climate Change 2(2): 137-152, SCIENCEDOMAIN international www.sciencedomain. org

14. IPCC Working Group II, Cambridge University Press. pp. 7450-7771.

15. MOFA (2007) Food and Agriculture Sector Development Policy (FASDEP II). Accra: Ministry of Food and Agriculture.

16. African Cashew Initiative (2010) A Value Chain Analysis of the Cashew Sector in Ghana; Deutsche Gesellschaft für Technische Zusammenarbeit GmbH (GTZ) International Foundations

17. Muller C, Cramer W, Hare W L, LotzeCampen H (2011) Climate change risks for African agriculture Proc. Natl Acad. Sci. USA 108: 4313-5.

18. Schahczenski J, Hill H (2009) Agriculture, Climate Change and Carbon Sequestration: A Publication of ATTRA - National Sustainable Agriculture Information Service 1-800-346-9140. www.attra.ncat.org

19. Sedjo R, Sohngen B (2012) Carbon Sequestration in Forests and Soils: The Annual Review of Resource Economics; annualreviews.org

20. M L Parry O F, Canziani J P, Palutikof P J, van der Linden C E, Hanson Eds, Boko M, Niang I, Nyong A, Vogel C, Githeko A, Medany M, Osman-Elasha B, Tabo B, Yanda P (2007) Africa. climate change 2007: Impacts, adaptation and vulnerability. Contribution of working group ii to the fourth assessment report of the intergovernmental panel on climate change, Cambridge University Press, Cambridge, UK, 433-467

21. Rome FAO (2004 a). The State of Agricultural Commodity Markets 2004. Rome.

22. FAO (2019) The State of Food and Agriculture 2019. Moving forward on food loss and waste reduction. Rome: Food and Agriculture Organization of the United Nations. doi:10.4324/9781315764788

Copyright: (C2020 Victor Adjei. This is an open-access article distributed under the terms of the Creative Commons Attribution License, which permits unrestricted use, distribution, and reproduction in anymedium, provided the original author and source are credited. 